\title{
ROLE OF COMBINING COLOUR DOPPLER AND GREY SCALE ULTRASOUND IN DIFFERENTIATING BENIGN FROM MALIGNANT OVARIAN MASSES
}

Muna Abid Al-Ghani Zghair ${ }^{1}$, Qays Ahmed Hassan², Rana Ahmed Mahdi ${ }^{3}$

${ }^{1}$ Section of Radiology, Department of Medicine, College of Medicine, Al-Mustansiriyah University, Baghdad, Iraq. ${ }^{2}$ Division of Radiology, Department of Surgery, Al-Kindy College of Medicine, University of Baghdad, Baghdad, Iraq. ${ }^{3}$ Department of Radiology, Al-Yarmook Teaching Hospital, Baghdad, Iraq.

\section{ULOGA KOMBINOVANE COLOR-DOPPLER I GRAY-SCALE ULTRAZVUČNE METODE U DIFERENCIJACIJI BENIGNIH OD MALIGNIH OVARIJALNIH PROMENA \\ Muna Abid Al-Ghani Zghair ${ }^{1}$, Qays Ahmed Hassan², Rana Ahmed Mahdi ${ }^{3}$ ${ }^{1}$ Odsek za radiologiju, Katedra za medicinu, Medicinski fakultet, Al-Mustansiriyah Univerzitet, Bagdad, Irak ${ }^{2}$ Odsek za radiologiju, Katedra za hirurgiju, Al-Kindy medicinski fakultet, Univerzitet u Bagdadu, Bagdad, Irak ${ }^{3}$ Katedra za radiologiju, Al-Yarmook univerzitetska bolnica, Bagdad, Irak}

Received / Primljen: 16. 03. 2018.

Accepted / Prihvaćen: 17. 07. 2018.

\section{ABSTRACT}

The aim of this study was to evaluate ovarian masses with conventional grey scale ultrasonography and colour Doppler flow imaging and to assess the diagnostic reliability of these methods in differentiating benign and malignant ovarian masses.

We assessed 56 patients with an ovarian mass. Morphological characterisation of the mass was performed utilising the Sassone score. Colour Doppler parameters were recorded for each patient, and the Caruso vascular score was also applied. The results were compared with surgical/pathological and/or follow-up scans.

Using the Sassone score, overall reliability in differentiating ovarian masses had a sensitivity of $89.5 \%$ and a specificity of 78.4\%. Using the Caruso score alone, we found a sensitivity of $89.5 \%$ and a specificity of $86.5 \%$. Using the Sassone and Caruso scores together, we found a sensitivity of $94.7 \%$ and a specificity of $89.1 \%$.

Combining both morphological and colour Doppler scores in the evaluation of ovarian masses obtained higher specificity, sensitivity, and accuracy than was obtained using a single score only.

Keywords: Ovarian mass, Ultrasonography, Vascular score, Malignant, Benign.

\section{INTRODUCTION}

The diagnosis of ovarian masses is a frequent dilemma in clinical work. Most ovarian masses are benign $(1,2)$. The most crucial step following identification of the ovarian mass is the perception of a level of malignancy; determining the level of malignancy will have a great impact on patient survival. It is the danger of malignancy that drives

\section{SAŽETAK}

Cilj ove studije bila je evaluacija ovarijalnih tumora konvencionalnom crno-belom ultrasonografijom kao i kolor-dopler metodom sa ciljem diferentovanja benignih i malignih osobina tumora.

Uključili smo 56 pacijenata sa tumorima ovarijuma. Morfološka karakterizacija tumora je urađena pomoću Sasson skora. Za svakog pacijenta odredeni su parametri pomoću kolor-dopler metode kao i Karuzo vaskularni skor. Ovi rezultati su upoređivani sa hirurškim i/ili patološkim nalazima.

Korišćenjem Sasson skora, opšta pouzdanost u proceni vrste ovarijalnih tumora ima senzitivnost od 89,5\% i specifičnost od 78,4\%. Korišćenjem Karuzo skora, pronašli smo senzitivnost od 89,5\% i specifičnost od 86,5\%. Upotrebom oba skora, Sassone i Karuzo, senzitivnost je bila 94,7\% a specifičnost čak 89,1\%.

Kombinovanjem morfoloških $i$ kolor-dopler skorova u evaluaciji i dijagnostici ovarijalnih tumora dobijamo veću specifičnost, senzitivnost i tačnost dijagnoze u odnosu na pojedinačno upotrebljene metode.

Ključne reči: Ovarijalni tumor, ultrasonografija, vaskularni skor, maligni, benigni

us to reliable and immediate diagnosis to decrease morbidity and mortality. Ovarian cancer represents a principle surgical difficulty in that it requires exhaustive and usually complicated therapies, and it greatly affects the patient's psychological and physical state. It has the greatest case fatality rate of all the gynaecological malignan-

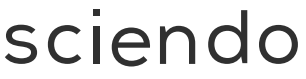

UDK: 618.11-006-073 Ser J Exp Clin Res 2020; 21 (2): 157-162 DOI: 10.2478/SJECR-2018-0069
Corresponding author: Qays Ahmed Hassan, University of Baghdad, Al-Kindy College of Medicine, Al-Nahdha square Postal address: 10071 University of Baghdad, Baghdad, Iraq, E-mail: qtimeme@yahoo.com, Cell phone: 9647722604163 
Table 1. Criteria used in Sassone score for sonomorphological characterisation (7)

\begin{tabular}{|c|c|c|c|c|c|}
\hline $\begin{array}{l}\text { Inner wall } \\
\text { structure }\end{array}$ & Smooth & $\begin{array}{l}\text { Irregularity } \\
\text { less than } 3 \mathrm{~mm}\end{array}$ & $\begin{array}{l}\text { Papillarities } \\
\text { more than } 3 \mathrm{~mm}\end{array}$ & Not applicable & - \\
\hline Septae & No septa & $\begin{array}{l}\text { Thin less than } \\
3 \mathrm{~mm}\end{array}$ & $\begin{array}{l}\text { Thick more } \\
\text { than } 3 \mathrm{~mm}\end{array}$ & - & - \\
\hline Wall thickness & $\begin{array}{l}\text { Thin less than } \\
3 \mathrm{~mm}\end{array}$ & $\begin{array}{l}\text { Thick more } \\
\text { than } 3 \mathrm{~mm}\end{array}$ & $\begin{array}{l}\text { Not applicable } \\
\text { mostly solid }\end{array}$ & - & - \\
\hline Echogenicity & Sonolucent & Low echogenic & $\begin{array}{l}\text { Low echogenic } \\
\text { with echogenic } \\
\text { core }\end{array}$ & $\begin{array}{l}\text { Mixed } \\
\text { echogenicity }\end{array}$ & $\begin{array}{l}\text { High } \\
\text { echogenicity }\end{array}$ \\
\hline
\end{tabular}

Benign: <9; Malignant: $\geq 9$

cies (3). Therefore, it is necessary to have a diagnostic tool for its immediate discovery and conventional treatment and to increase survival. Therefore, we want diagnostic means that allow proper classification of ovarian masses before surgery; hence, it is essential to identify the nature of the tumour before surgery. Ultrasonography (USG) is regarded as the basic imaging modality for recognising the nature of the ovarian mass as benign or malignant (4). USG morphologic assessment is still the most common modality for detecting ovarian cancer (5). USG relates morphologic images with gross macroscopic pathologic characteristics of ovarian masses. However, when morphologic characteristics only are used to predict the ovarian malignancy, there is a tendency to over-diagnose malignant tumours because of a large overlap between malignant and benign masses. Accordingly, the addition of colour Doppler imaging with pulsed Doppler spectral analysis enhances the characterisation of ovarian masses by means of quantitative blood flow measurements obtained from tumour vessels and thus improves sensitivity and specificity of the characterisation of ovarian masses (1-4). High operator dependence and extreme variability in the characteristics of ovarian tumours make a definite diagnosis still difficult. To overcome these limitations, applying scoring systems has been promoted. These scoring systems, joining various parameters of USG and colour Doppler, raise the sensitivity and specificity of diagnosis with excellent accuracy (6).

The purpose of this study was to evaluate the ovarian masses with conventional grey scale and colour Doppler flow imaging and to assess the diagnostic reliability of these methods in differentiating benign and malignant ovarian masses.

\section{MATERIALS AND METHODS}

This prospective study was carried out between $\mathrm{Au}$ gust 2015 and January 2017. The study included 56 patients who were clinically suspected to have ovarian neoplasm and referred for USG and Doppler examinations. Ethical clearance for the study was obtained from our local institutional scientific and ethics committee with approval number 32 / 2015 before the commencement of the study. Informed consent for all participating patients was obtained. All patients were examined on GE Voluson E6 Color Doppler Machine with 3.5-5 MHz convex and 7.5 $\mathrm{MHz}$ transvaginal transducers and with grey scale, power, and spectral Doppler. The detailed history of all patients was studied, and complete examination was performed. USG preferably was performed during the proliferative phase of the menstrual cycle in premenopausal women. The same radiologist evaluated all the cases. Scanning was performed in the supine position. The whole of the abdominal cavity was scanned in longitudinal and axial plane with particular reference to the pelvic cavity. The ovaries were recognised. Ovarian masses in either ovary, if seen, were assessed. In uncertain cases of ovarian masses on transabdominal USG, transvaginal USG was done to exclude extra-ovarian masses. The Sassone scoring system on the basis of morphological parameters was applied where a score $\geq 9$ is considered to be probably malignant. Table 1 shows the Sassone scoring system, which is based on the visualisation of the inner wall structure, wall thickness, septae and solid part echogenicity. Subsequently, power and Doppler flow imaging and spectral analysis were performed. Doppler parameters were optimised for detection of flow and calculation of impedance indices. Flow results were recorded as being absent or present and further characterised as normal or increased. Normal flow was characterised by fine branching vessels, no evidence of "hot-spots"/aliasing, and presence of peripheral flow. The flow was classified as increased if di-

Table 2. Criteria used in Caruso score (8)

\begin{tabular}{lll}
\hline & Absent & 0 \\
Vessels location & Present & 1 \\
& Peripheral & 0 \\
& Septal & 1 \\
& Central & 2 \\
Arrangement of vessels & Regular & 0 \\
& Random & 2 \\
Waveform pattern & Sharp with diastolic notch & 0 \\
& Smooth without notch & 2 \\
\hline
\end{tabular}

*Benign: <5; Malignant: $\geq$ 5. RI: Resistive index 
Table 3. Distribution of ovarian masses according to age and parity.

\begin{tabular}{|c|c|c|c|c|}
\hline \multicolumn{5}{|c|}{ Histopathology } \\
\hline & & $\begin{array}{c}\text { Malignant } \\
\%\end{array}$ & $\begin{array}{c}\text { Benign } \\
\%\end{array}$ & P value \\
\hline \multirow{5}{*}{ Age } & $<30$ & 21.1 & 29.7 & 0.287 \\
\hline & $30---39$ & 15.8 & 32.4 & \\
\hline & $40---49$ & 15.8 & 13.5 & \\
\hline & $=>50$ & 47.4 & 24.3 & \\
\hline & Mean \pm SD (Range) & $45.0 \pm 15.5(20-67)$ & $38.2 \pm 12.2(20-67)$ & \\
\hline \multirow{6}{*}{ Parity } & Nulliparous & 26.3 & 16.2 & 0.016 \\
\hline & P1 & 10.5 & 37.8 & \\
\hline & P2 & 10.5 & 29.7 & \\
\hline & P3 & 26.3 & 10.8 & \\
\hline & P4 \& more & 26.3 & 5.4 & \\
\hline & Mean \pm SD (Range) & $2.3 \pm 1.8(0-5)$ & $1.5 \pm 1.1(0-4)$ & \\
\hline
\end{tabular}

SD: Standard deviation, P: Para.

lated prominent parenchyma vessels were present; "hotspots" and aliasing were seen in colour flow mapping. The vessel location (peripheral, central, and septal), arrangement (regular/random) and morphology (normalfine tapering vessels versus abnormal dilated prominent vessels, focal stenosis, aneurysms, blind-ending lakes and dichotomous branching) were also noted. Spectral Doppler study including RI (Resistivity index), PI (Pulsatility index), PSV (Peak systolic velocity) and presence or absence of dicrotic notch were recorded in each patient. Caruso score (Table 2) was applied for further characterisation of the mass where a score $\geq 5$ was supposed indicative of malignancy. Benign and malignant classification of the ovarian masses was done depending upon the grey scale and colour Doppler USG. The results were correlated with the histopathological findings.

Table 4. The histopathological diagnosis of the studied ovarian masses.

\begin{tabular}{|c|c|c|}
\hline & Histopathological diagnosis & No. (\%) \\
\hline \multirow{9}{*}{ Benign } & Serous cystadenoma & $8(14.29)$ \\
\hline & Mucinous cystadenoma & $4(7.14)$ \\
\hline & Mature teratoma & $13(23.21)$ \\
\hline & Haemorrhagic cyst & $5(8.93)$ \\
\hline & Fibrothecoma & $2(3.57)$ \\
\hline & Serous cystadenofibroma & $2(3.57)$ \\
\hline & Endometriosis & $2(3.57)$ \\
\hline & Epidermoid cyst & $1(1.79)$ \\
\hline & Total & $37(66.07)$ \\
\hline \multirow{7}{*}{ Malignant } & Serous cystadenocarcinoma & $5(8.93)$ \\
\hline & Mucinous cystadenocarcinoma & $3(5.35)$ \\
\hline & Endometroid adenocarcinoma & $2(3.57)$ \\
\hline & Immature teratoma & $7(12.50)$ \\
\hline & Brenner cell & $1(1.79)$ \\
\hline & Fibrosarcoma & $1(1.79)$ \\
\hline & Total & $19(33.93)$ \\
\hline
\end{tabular}

\section{Statistical analysis}

Statistical Package for the Social Sciences version 20 (SPSS 20) was used for both data entry and data analysis. Discrete variables were displayed as a number (\%). Chisquare test (or Fisher's exact test when appropriate) was used to test the significance of the relationship for the discrete variable. $\mathrm{P}$-value of $<0.05$ was regarded as significant.

\section{RESULTS}

Fifty-six patients were included in this study. Thirtyeight (68\%) patients were pre-menopausal, and 18 (32\%) were postmenopausal women. The mean $( \pm \mathrm{SD})$ age of patients included in the study was $45.0 \pm 15.5$ years (range 2067 years) for malignant masses and $38.2 \pm 12.2$ years (range 20-67 years) for benign masses. In correlation with the parity, the malignant masses were significantly noted more among nulliparous and para 3 women, while the benign masses were more among para 1 women. Table 3 shows the distribution of the ovarian masses according to age and parity. Table 4 summarises the histopathological diagnosis of 56 ovarian masses studied where 37 (66.07\%) were benign and 19 (33.93\%) were malignant.

Table 5 shows the distribution of 56 patients according to the Sassone, Caruso and combined scoring systems and its correlation to the finally confirmed histopathological diagnosis. Out of 37 benign cases, the Sassone scoring system alone was able to diagnose 29 (78.3\%) cases, the Caruso scoring system alone was able to identify 32 (86.4\%) cases, and the combined scoring system was able to identify $33(89.1 \%)$ cases. Out of 19 malignant cases, the Sassone scoring system alone was able to diagnose 17 (89.4\%) cases, the Caruso scoring system alone was able to diagnose 17 $(89.4 \%)$ cases, and the combined scoring system was able to diagnose 18 (94.7\%) cases. These findings, regarding the Sassone scoring system alone, had a sensitivity of $89.5 \%$, a specificity of $78.4 \%$, a positive predictive value (PPV) of 
Table 5. Comparison between Sassone, Caruso and combined scoring systems and histopathology

\begin{tabular}{llll}
\hline & Benign & Malignant & Total \\
\hline $\begin{array}{l}\text { Sassone score } \\
\text { Benign }(0-8)\end{array}$ & 29 & 2 & 31 \\
Malignant $(\geq 9)$ & 8 & 17 & 25 \\
& 37 & 19 & \\
Caruso score & 32 & 2 & 34 \\
Benign $(<5)$ & 5 & 17 & 22 \\
Malignant $(\geq 5)$ & 37 & 19 & \\
Combined score & & & \\
Benign & 33 & 1 & 34 \\
Malignant & 4 & 18 & 22 \\
& 37 & 19 & \\
\hline
\end{tabular}

$86.0 \%$, a negative predictive value (NPV) of $93.5 \%$ and an accuracy of $82.1 \%$; the findings of the Caruso scoring system alone had a sensitivity of $89.5 \%$, a specificity of $86.5 \%$, a PPV of $77.3 \%$, an NPV $94.1 \%$ and an accuracy of $87.5 \%$. Using both the Sassone and Caruso scores together, we found a sensitivity of $94.7 \%$, a specificity of $89.1 \%$, a PPV of $81.8 \%$, an NPV of $97.0 \%$ and an accuracy of $91.0 \%$.

Table 6 gives comparative efficacy of Sassone, Caruso, and combined scoring systems in differentiating benign from malignant ovarian masses and shows that the combined scoring system is a better performing scoring system.

\section{DISCUSSION}

Today, the commonly applied means for distinguishing between malignant and benign ovarian masses are the physical examination, serum tumour markers, and grey scale and colour Doppler USG (9). Colour and pulsed Doppler can improve preoperative diagnosis of ovarian tumours when compared to transvaginal sonography alone or tumour marker assessment (10). Although grey scale USG is sensitive in identifying ovarian carcinoma, its reliability has not been enough to preclude further invasive methods, such as laparoscopy and laparotomy. Colour Doppler imaging and spectral Doppler imaging have been reviewed as potential means of increasing the specificity of grey-scale USG in differentiating benign from malignant masses $(11,12)$.

Timmerman D et al.(13) in their prospective validation study, which was conducted in 19 USG centres in

Table 6. Statistical comparison between two scoring systems

\begin{tabular}{llll}
\hline $\begin{array}{l}\text { Statistical } \\
\text { parameter }\end{array}$ & $\begin{array}{l}\text { Sassone scoring } \\
\text { system \% }\end{array}$ & $\begin{array}{l}\text { Caruso scoring } \\
\text { system \% }\end{array}$ & $\begin{array}{l}\text { Combined } \\
\text { scoring } \\
\text { system \% }\end{array}$ \\
\hline Sensitivity & 89.5 & 89.5 & 94.7 \\
Specificity & 78.4 & 86.5 & 89.1 \\
PPV & 68.0 & 77.3 & 81.8 \\
NPV & 93.5 & 94.1 & 97.0 \\
Accuracy & 82.1 & 87.5 & 91.0 \\
\hline
\end{tabular}

PPV: Positive predictive value, NPV: Negative predictive value

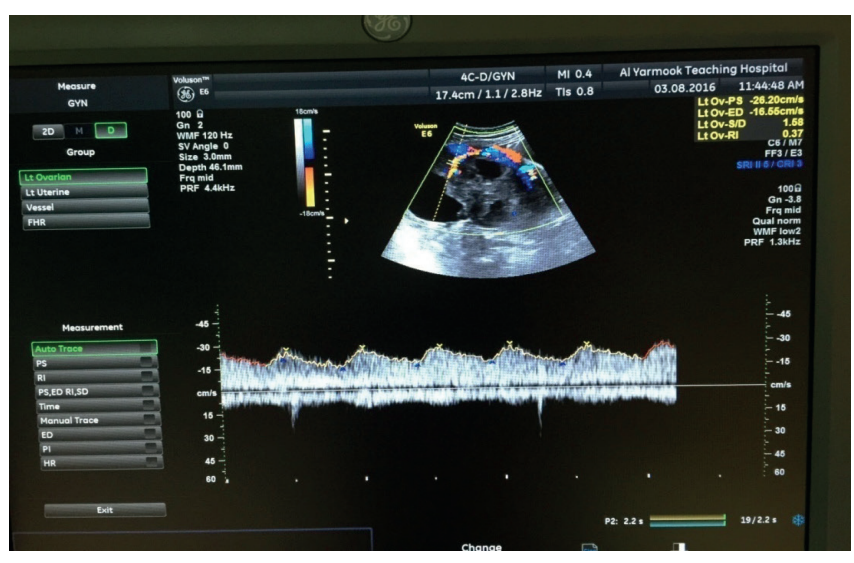

Figure 1. Spectral Doppler USG of 47 year-old patient shows complex ovarian mass with internal vascularity and low $\mathrm{RI}=0.37$ diagnosed as serous cyst adenocarcinoma on histopathology

eight countries, concluded that the use of the simple USG rules (shape, size, solidity, and results of colour Doppler examination) to distinguish benign from malignant ovarian masses has the potential to improve the management of women with an ovarian mass.

Characteristics that raise the suspicion of malignancy in USG include the presence of thick septa, papillary projections, heterogeneous echotexture, and septa greater than $3 \mathrm{~mm}$ in thickness or which have flow on colour Doppler USG $(14,15)$. Neovascularisation in the tumour always offers lower resistance to blood flow in malignant neoplasms (Fig 1).

Benign tumours have been characterised as being unilocular, with thin septae, homogenous iso echogenicity and thin wall capsule (16).

In our study, using only a grey scale Sassone scoring system, out of 37 benign tumours, 29 were correctly diagnosed and 8 were misdiagnosed. Out of 19 malignant tumours, 17 were correctly diagnosed as malignant and 2 were misdiagnosed as benign. Using Caruso scoring system, out of 19 malignant masses, 17 were correctly diagnosed. Using the combination of both scoring systems, out of 19 malignant cases 18 were correctly diagnosed. The only case, which was not diagnosed, was of immature teratoma. In this case, the tumour was of mixed echogenicity without solid mass or vascularisation. Accordingly, out of 37 benign masses, 33 were correctly diagnosed as benign and 4 were misdiagnosed as malignant; these were 2 cases of fibrothecoma and 2 cases of serous cystadenofibroma. In these cases, the tumours were encountered as unilocular cysts with solid areas and central flow.

In our study, Colour Doppler results showed predominantly peripheral localisation of vessels in benign masses (65\%) and predominantly central or septal vessel localisation (81.8\%) in malignant masses. This agrees with the results of Jokubkiene et al. (17) who found that $57 \%$ of benign masses showed peripheral vascularisation versus $70 \%$ of malignant masses that showed central vascularisation.

In our study, the RI alone was an insufficient discriminating parameter, as there was overlap between benign and 
malignant masses. The RI cut-off value of $<0.43$ used had a significant p-value $(<0.0005)$. Pulsatility index $<1.0$ had a sensitivity of $73.6 \%$ and a specificity of $64.9 \%$, and there was a significant overlap between malignant and benign masses. Ueland et al. (16) reported sensitivity and specificity of $52.8 \%$ and $77.6 \%$, respectively, using the cut-off value of $\mathrm{PI}<1$. In spite of that, Abbas et al. (18) reported that $\mathrm{PI}<$ 1 was an important feature of malignancy $(80.4 \%)$, but $\mathrm{PI}<$ 1 was also found in $15.7 \%$ of benign masses. Thus PI alone cannot be a reliable parameter to detect malignancy. Shah D et al. (19) reported sensitivity (97.5 \%) and specificity (84.1\%) with $P I$ and $R I$ values of $<1.0$ and $<0.6$, respectively, in their multi-parameter analysis utilising B-mode USG along with Colour Doppler and Spectral Doppler to differentiate between malignant and benign ovarian tumours. These findings are correlated with our result.

In the present study, B mode USG along with Doppler showed a sensitivity of $94.7 \%$, a specificity of $89.1 \%$, a PPV of $81.8 \%$, an NPV of $97.0 \%$ and an accuracy of $91.0 \%$. These results agreed with those of Abbas et al. (18) who were using a new scoring model (Assiut Scoring Model $\{$ ASM $\}$ ), in which they used two-dimensional USG and Doppler features and showed a sensitivity of $93.5 \%$, a specificity of 92.2\%, a PPV of $82.7 \%$ and an NPV of $97.3 \%$, with overall accuracy of $92.6 \%$. Our results also agree with the results of Dhwani et al. (20), who conclude that using the combination of both grey scale and colour Doppler in differentiating benign from malignant ovarian masses gives results with more accuracy. Furthermore, our results agree with those of Malhotra A et al. (21), who conclude that grey scale USG combined with Colour and Spectral Doppler is superior to grey scale USG alone in differentiating benign and malignant adnexal masses. Gagandeep et al. (22) evaluated 30 patients with ovarian mass in their study, and they showed a sensitivity of $91.7 \%$ and a specificity of $77.7 \%$ when using the Sassone score alone, a sensitivity of $83.3 \%$ and a specificity of $88.9 \%$ when using Caruso score alone, and a sensitivity of $90.9 \%$ and a specificity of $93.3 \%$ when using both scores together. These findings are well correlated with our results.

Based on the results of our study, patients with masses score $<5$ can be managed in the gynaecological unit by a gynaecologist, either conservatively or surgically, according to their features. Patients with masses score $\geq 8$ must be referred to a gynaecological oncologist and be managed in specialised oncology centres. Patients with masses score 4-6 are suspicious with high possibility of malignancy if score $\geq 6$, so further investigations may be ordered such as MRI.

\section{CONCLUSION}

There is significant overlap in the morphologic features of different ovarian masses. The combination of grey scale USG with colour and spectral Doppler is recommended as the leading diagnostic modality in patients with an ovarian tumour. This combination gives better diagnostic achievement than an individual method and accordingly will establish the definite diagnosis of malignancy early in the course of the disease.

\section{REFERENCES}

1. Barney SP, Muller CY, Bradshaw KD. Pelvic masses. Med Clin North Am. 2008;92:1143-1161.

2. Ackerman S, Irshad A, Lewis M, Anis M. Ovarian cystic lesions: a current approach to diagnosis and management. Radiol Clin North Am. 2013;51:1067-1085.

3. Valentin L, Ameye L, Franchi D, Guerriero S, Jurkovic D, Savelli L, et al. Risk of malignancy in unilocular cysts: a study of 1148 adnexal masses classified as unilocular cysts at transvaginal ultrasound and review of the literature. Ultrasound Obstet Gynecol. 2013;41:80-89.

4. Medeiros LR, Rosa DD, da Rosa MI, Bozzetti MC. Accuracy of ultrasonography with color Doppler in ovarian tumor: a systematic quantitative review. Int J Gynecol Cancer. 2009;19:1214-1220.

5. Laing FC, Allison SJ. US of the ovary and adnexa: to worry or not to worry? Radiographics. 2012;32:16211639.

6. Alcázar JL, Mercé LT, Laparte C, Jurado M, LópezGarcía G. A new scoring system to differentiate benign from malignant adnexal masses. Am J Obstet Gynecol 2003;88:685-692.

7. Sassone AM, Timor-Tritsch IE, Artner A, Westhoff C, Warren WB. Transvaginal sonograpihic characterization of ovarian disease: evaluation of a new scoring system to predict ovarian malignancy. Obstet Gynccol 1991;78:70-76.

8. Caruso A, Caforio L, Testa AC, Ciampelli M, Panici PB, Mancuso S. Transvaginal color Doppler ultrasonography in the presurgical characterization of adnexal masses. Gynecol Oncol.1996;63: 184-191.

9. Van Calster B, Timmerman D, Bourne T, Testa AC, Van Holsbeke C, Domali E, et al. Discrimination between benign and malignant adnexal masses by specialist ultrasound examination versus serum CA-125. J Natl Cancer Inst. 2007;99:1706-1714.

10. Jung SI. Ultrasonography of ovarian masses using a pattern recognition approach. Ultrasonography. 2015;34:173-182.

11. Levine D, Brown DL, Andreotti RF, Benacerraf B, Benson $\mathrm{CB}$, Brewster WR, et-al. Management of asymptomatic ovarian and other adnexal cysts imaged at US: Society of Radiologists in Ultrasound Consensus Conference Statement. Radiology. 2010;256:943-954.

12. Gupta KP, Jain SK. Role of Ultrasonography and Color Doppler to Diagnosis of Pelvic Masses and its Correlation with Histopathological Findings. Int J Sci Stud 2016;4:147-153

13. Timmerman D, Ameye L, Fischerova D, Epstein E, Melis GB, Guerriero S, et al. Simple ultrasound rules 
to distinguish between benign and malignant adnexal masses before surgery: prospective validation by IOTA group. BMJ. 2010 Dec 14;341:c6839.

14. Secil M, Dogra VS. Color Flow Doppler Evaluation of Uterus and Ovaries and Its Optimization Techniques. Ultrasound Clinic 2008; 3: 461-482.

15. Farnaz, Wahab S, Hassan L. Women with Ovarian Masses. J Postgrad Med Inst 2012; 26: 73-78.

16. Ueland FR, DePriest PD, Pavlik EJ, Kryscio RJ, van Nagell JR. Preoperative differentiation of malignant from benign ovarian tumors: the efficacy of morphology indexing and Doppler flow sonography. Gynecol Oncol. 2003;91:46-50.

17. Jokubkiene L, Sladkevicius P, Valentin L. Does three dimensional power Doppler ultrasound help in discrimination between benign and malignant ovarian masses? Ultrasound Obstet Gynecol. 2007;29:215-225.

18. Abbas AM. Zahran KM, Nasr A, Kamel HS. A new scoring model for characterization of adnexal masses based on two-dimensional gray-scale and colour Doppler sonographic features. Facts Views Vis Obgyn. 2014;6:68-74.

19. Shah D, Shah S, Parikh J, Bhatt CJ, Vaishnav K, Bala DV. Doppler Ultrasound: A Good and Reliable Predictor of Ovarian Malignancy. J Obstet Gynaecol India. 2013;63:186-189.

20. Dhwani D, Desai VA, Verma RN, Shrivastava A. Role of gray scale and color Doppler in differentiating benign from malignant ovarian masses. J Midlife Health. 2010;1:23-25.

21. Malhotra A, Tarafdar S, Tayade AT. Benign versus malignant adnexal masses: Does addition of Color and Spectral Doppler over and above the Gray Scale Ultrasound improves diagnostic efficacy. Sch. J. App. Med. Sci. 2016;4:62-74.

22. Gagandeep C, Avneet B, Gurinder S, Deepak G, Manjit KM, Sanjay S. Role of combining colour Doppler and grey scale ultrasound in characterizing adnexal masses. Journal of Family and Reproductive Health. 2012;6:42-47. 